\title{
Har silibinin en plass i behandlingen av leversykdommer?
}

\author{
Medikamentet silibinin brukes i en del land og påstås å ha en leverprotektiv effekt. Vi har nylig utredet en pasient \\ som fikk reversert patologiske leververdier etter at hun ble forskrevet medikamentet i utlandet. Bedre doku- \\ mentasjon er imidlertid nødvendig før medikamentet kan tas i bruk i behandling av leversykdommer.
}

En kvinne i 40-årene ble henvist til medisinsk poliklinikk grunnet vedvarende lett forhøyede leverprøver. Hun hadde aldri brukt naturmedisiner og sjelden drukket alkohol. Utvidede blodprøver viste forhøyede lever-/ galleprøver. Hepatittserologi var negativ, og immunologiske prøver var normale.

Det var planlagt videre utredning, men pasienten reiste i mellomtiden på ferie til hjemlandet. Hun fikk der ordinert «Lagosa (silibinin)» for høye leverprøver uten sikker diagnose. Ved kontroll i Norge hadde hun brukt medisinen i over to måneder. Blodprøvene viste da at alle leverprøvene var normale, unntatt lett forhøyet gammaglutamyltransferase (GT). Tre måneder senere hadde hun fremdeles stabilt lave leverprøver.

\section{Bakgrunn}

«Silymarin» har vært brukt i mange år for behandling av leversykdommer, hovedsakelig ikke-alkoholisk fettlever. Den første publikasjonen om silymarin kom allerede i 1968 (1). Silymarin er et renset ekstrakt fra Maria-tistel (Silybum marianum) og inneholder fire komponenter der den dominerende og mest biologisk aktive komponenten er silibinin $(2,3)$. Silibinin forbedrer aktiviteten til levercellene og bidrar til å gjenopprette deres funksjon etter ulike type skader. Stoffene virker ved å være antioksidanter, stabilisere cellemembraner, fremme syntese av ribosomalt RNA og stimulere leverens regenerering $(3,4)$. Legemidlene er tilgjengelig i blant annet Tyskland, Tsjekkia, Georgia, Polen, Romania og Slovakia.

\section{Kliniske studier på Silymarin}

Flere studier har vurdert effekten av silymarin ved tilstander som fettlever, primær skleroserende kolangitt, primær biliær cirrhose og hepatitt C-infeksjon (5-7). Eksperimentelle studier har vist motstridende resultater mht. leverprotektiv effekt, og hos rotter er effekten avhengig av skademekanismen $(8,9)$.

Det finnes ingen konsensus om hvordan ikke-alkoholisk fettlever skal behandles, og silymarin/silibinin er foreslått (10). Vi har funnet to studier der man ser på effekten av medikamentene ved tilstanden. I en randomisert studie ble effekten av metformin, pioglitazon og silymarin sammenliknet (4). 66 pasienter ble delt inn i tre like store grupper som tok et av de tre medikamentene $i$ to måneder. Alle gruppene hadde signifikant bedring i leverprøvene, men reduk- sjonen var størst i silymaringruppen. Studien var liten og ikke placebokontrollert, og enhver intervensjon (kostholdsendring, vekttap osv.) kan gi bedring ved fettlever. Den andre studien inkluderte 72 pasienter, og her fant man at graden av fettlever målt ved ultralyd og blodprøver var signifikant lavere etter seks måneders behandling (5).

Hos pasienter med primær skleroserende kolangitt og primær biliær cirrhose er det også blitt utført pilotstudier med silibininbehandling i et år. En tredel av pasientene med primær skleroserende kolangitt fikk en betydelig forbedring $i$ alkaliske fosfataser (ALP) og aspartataminotransferase (ASAT) (6), men silibinin hadde ikke bedre effekt enn standardbehandling (ursodeoksykolsyre) hos pasienter med primær biliær cirrhose (7).

I de siste årene har silibinin dukket opp som potensielt medikament ved hepatitt Cinfeksjon. Den antivirale mekanismen er imidlertid fortsatt uklar, og flere mekanismer har vært postulert (11).

På det norske legemiddelmarkedet fås silibinin kun på godkjenningsfritak som infusjon til bruk ved soppforgiftninger. Preparatet er ikke et spesifikt antidot, men antas å øke urinutskillingen av toksiner ved blant annet å redusere opptaket $\mathrm{i}$ hepatocyttene (12).

\section{Konklusjon}

Vår pasient brukte silibinin før diagnosen ble avklart. Vi ønsker å informere norske leger om silibinin siden pasienter noen ganger får helsehjelp i utlandet, hvor preparatet er mye brukt. Det mangler imidlertid både randomiserte placebokontrollerte kliniske studier og oppfølgingsstudier. Mer vitenskapelig dokumentasjon er påkrevd før man kan anbefale dette preparatet i klinisk bruk for leversykdommer.

Pasienten har gitt samtykke til at artikkelen blir publisert.

\section{Gülen Arslan Lied}

gulen.arslan@med.uib.no

Odd Helge Gilja

Trygve Hausken

Gülen Arslan Lied (f. 1972) er spesialist i indremedisin og i fordøyelsessykdommer, professor II og overlege.

Forfatter har fylt ut ICMJE-skjemaet og oppgir ingen interessekonflikter.
Odd Helge Gilja (f. 1962) er spesialist i indremedisin og i fordøyelsessykdommer, professor Il og overlege.

Forfatter har fylt ut ICMJE-skjemaet og oppgir ingen interessekonflikter.

Trygve Hausken (f. 1951) er spesialist i indremedisin og i fordøyelsessykdommer, professor og overlege.

Forfatter har fylt ut ICMJE-skjemaet og oppgir ingen interessekonflikter.

\section{Litteratur}

1. Wagner $\mathrm{H}$, Hörhammer L, Münster R. On the chemistry of silymarin (silybin), the active principle of the fruits from Silybum marianum (L.) Gaertn. (Carduus marianus L.). Arzneimittelforschung 1968; 18: 688-96.

2. Gopalakrishnan R, Sundaram J, Sattu K et al. Dietary supplementation of silymarin is associated with decreased cell proliferation, increased apoptosis, and activation of detoxification system in hepatocellular carcinoma. Mol Cell Biochem 2013; 377: 163-76.

3. Polyak SJ, Oberlies NH, Pécheur El et al. Silymarin for HCV infection. Antivir Ther 2013; 18: 141-7.

4. Hajiaghamohammadi AA, Ziaee A, Oveisi S et al. Effects of metformin, pioglitazone, and silymarin treatment on non-alcoholic Fatty liver disease: a randomized controlled pilot study. Hepat Mon 2012; 12: e6099.

5. Cacciapuoti F, Scognamiglio A, Palumbo R et al. Silymarin in non alcoholic fatty liver disease. World J Hepatol 2013; 5: 109-13.

6. Angulo P, Jorgensen RA, Kowdley KV et al. Silymarin in the treatment of patients with primary sclerosing cholangitis: an open-label pilot study. Dig Dis Sci 2008; 53: 1716-20.

7. Angulo P, Patel T, Jorgensen RA et al. Silymarin in the treatment of patients with primary biliary cirrhosis with a suboptimal response to ursodeoxycholic acid. Hepatology 2000; 32: 897-900.

8. Sherif 10, Al-Gayyar MM. Antioxidant, anti-inflammatory and hepatoprotective effects of silymarin on hepatic dysfunction induced by sodium nitrite. Eur Cytokine Netw 2013; 24: 114-21.

9. Cordero-Pérez P, Torres-González L, AguirreGarza M et al. Hepatoprotective effect of commercial herbal extracts on carbon tetrachlorideinduced liver damage in Wistar rats. Pharmacognosy Res 2013; 5: 150-6.

10. Farrell GC, van Rooyen D, Gan L et al. NASH is an inflammatory disorder: pathogenic, prognostic and therapeutic implications. Gut Liver 2012; 6: 149-71.

11. Polyak SJ, Ferenci P, Pawlotsky JM. Hepatoprotective and antiviral functions of silymarin components in hepatitis $C$ virus infection. Hepatology 2013; 57: 1262-71.

12. Svendsen BS, Gjellestad A, Eivindson $G$ et al. Alvorlige soppforgiftninger med giftslørsopper og hvit fluesopp. Tidsskr Nor Lægeforen 2002; 122: $777-80$.

Mottatt 12.6. 2013, første revisjon innsendt 9.1. 2014, godkjent 23.1. 2014. Redaktør: Kristin Viste.

Publisert først på nett. 